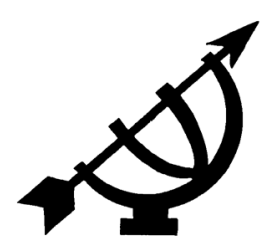

\title{
Female leaders in an international evangelical mission organisation: an empirical study of Youth With A Mission in Germany
}

\author{
F.A.S. Hornstra-Fuchs \& W.L. Hornstra1 \\ Department of Philosophy and Systematic Theology \\ University of South Africa \\ PRETORIA \\ and \\ School of Biblical Studies \\ University of the Nations \\ HURLACH \\ Germany \\ E-mail: wilrensandfranziska@sbsgermany.de
}

\begin{abstract}
Female leaders in an international evangelical mission organisation: an empirical study of Youth With A Mission in Germany
\end{abstract}

Evangelicals are frequently perceived as conservative, for instance in their perspective on women. There is indeed a widespread evangelical hierarchical or complementarian theological view which objects to women in church leadership. There is, however, a growing egalitarian counter position, sometimes also referred to as "evangelical feminism", which supports female leadership.

This article concentrates on the international missionary organisation Youth With A Mission (YWAM), which clearly endorses female leaders in formal statements. In YWAM Germany, however, women are under-represented in leadership positions.

1 The research on which this article is based was undertaken while F.A.S. Hornstra-Fuchs was registered as an M.Th. student in the then Department of Systematic Theology and Theological Ethics at the University of South Africa. 
The article seeks to explain this under-representation, especially in terms of the role played by Scripture.

By means of interviews with leaders in YWAM Germany, possible answers were explored. Surprisingly, for an evangelical organisation, the interpretation of Scripture proved not to be a significant factor. Factors that do play a role are church background, the lack of female role models, lower self-confidence of women, family responsibilities, and the role of incumbent leadership. The latter appears to be the most crucial factor, since the incumbent leaders, who mostly are men, select and appoint new leaders. It is likely that in this they are influenced by stereotypical conceptions of the leader as male and are inclined to appoint leaders similar to themselves.

\section{Opsomming}

\section{Vroulike leiers in ' $n$ internasionale evangeliese sendingorganisasie: ' $n$ empiriese ondersoek in Youth With A Mission in Duitsland}

Evangeliese Christene word dikwels gesien as konserwatief, byvoorbeeld met betrekking tot hulle perspektief op vroue in die bediening. Daar bestaan inderdaad 'n breed aanvaarde hiërargiese en komplimentêre evangeliese teologiese perspektief wat probleme het met vroue se leierskap in die kerk. Daar is egter ook 'n groeiende egalitêre teenposisie wat die leierskap van vroue ondersteun.

Hierdie artikel fokus op die internasionale sendingorganisasie Youth With A Mission (YWAM), wat die beginsel van vroue in leierskapsposisies duidelik in formele uitsprake ondersteun. In YWAM Duitsland is vroue onderverteenwoordig in leiersposisies. Hierdie artikel poog om hierdie onderverteenwoordiging te verduidelik, veral met betrekking tot die rol wat die Bybel speel.

Deur middel van onderhoude met leiers in YWAM Duitsland word na moontlike antwoorde gesoek. Verrassend genoeg blyk dit dat die interpretasie van die Bybel nie 'n deurslaggewende rol hierin speel nie. Faktore wat 'n rol speel is eerder kerklike agtergrond, 'n gebrek aan vroulike rolmodelle, minder selfvertroue by vroue, verantwoordelikhede in die gesin en die rol van bestaande leiers. Laasgenoemde blyk die mees deurslaggewende faktor te wees, omdat die leiers wat nuwe leiers selekteer en aanstel tans meestal mans is. Dit is waarskynlik dat hulle hierin beïnvloed word deur 'n stereotipiese beeld van leierskap en voorkeur gee aan manlike leiers. 


\section{Introduction}

Although much has changed in relation to female leadership during the past half century, it still cannot be automatically assumed that women are eligible to be appointed to leadership positions. If it could, there would be no need to include a special chapter on women in leadership handbooks (Neuberger, 2002:763-827; Chemers, 1997:140-150), nor would there be a far larger number of publications dealing with female leadership than with male leadership such as this article.

One repeated topic in such publications is the under-representation of women in leadership positions. This article is based on a M.Th. research dissertation that was successfully completed at the University of South Africa (Hornstra-Fuchs, 2009). It investigated explanations for the under-representation of women leaders within the evangelical missionary organisation Youth With A Mission (YWAM) in the German context.

After a brief discussion of evangelical views on women in leadership and the potentially positive role that evangelical theology could play, this article will introduce the evangelical organisation in question and present a summary of the actual research and its results.

\section{Evangelicals and female leadership}

Change relating to female leadership has also come to the evangelical movement, sparking passionate and controversial debate. This section concentrates on the situation in North America, but exactly the same debate, in part based on American sources, has entered the German scene, as indicated below (for Germany, see especially Schmalenbach, 2007; for a more extensive overview than presented below, see Hornstra-Fuchs, 2009:62-82).

There is a stereotypical perception of evangelicalism as conservative. Although this stereotype does exist, as exemplified by the "Christian Right" in America, it is far from the whole story. David Gushee (2008) has argued that an evangelical centre is emerging in American politics (implying that there is even an - albeit small evangelical left, epitomised since the 1970s by Jim Wallis and the Sojourners). These evangelicals take surprising positions - surprising, that is, if one only knows the right-wing caricature - on issues like climate change, mild forms of torture, poverty, and injustice, to mention some of the more important ones. 
Similarly, substantial diversity exists among evangelical views about women in leadership. There is of course the widespread complementarian view as represented by the Council on Biblical Manhood and Womanhood (CBMW). Proponents of this view often consider it the traditional Christian position, although many of them have softened the harshness of a consistently hierarchical view of gender. To them, the Bible plainly teaches that women and men have been created for different roles and thus complement each other. Leadership, at least in church and family, and for some, leadership in general, is male. This view is upheld in numerous works both of a popular nature and of a more scholarly bent. A broad academic defence of this position was published by Piper and Grudem (1991). The key word here is defence; it is a reaction to a growing counter movement referred to in the subtitle as "evangelical feminism" - a clever choice of words, as pointed out by Gallagher (2004), because of the negative connotation that the term feminism has for many evangelicals.

Evangelical feminists are, however, more likely to describe themselves as "egalitarians". Their main organisation is Christians for Biblical Equality (CBE), founded, like the CBMW, in 1987. They argue that the Bible, properly understood, supports the full equality of men and women; this implies that no office or ministry is closed to women simply on the basis of gender. 2 The fundamental issue here is not just exegesis, but rather hermeneutics. What in Scripture is universal, and what is cultural and contextual? Does one begin with the creation narratives or with passages like 1 Corinthians 14 and 1 Timothy 2? And what weight does one give to the specific historical setting of a passage? Does it explain the apparent exclusion of women as a directive limited to this setting or as a misunderstanding of the real intent, or does the passage establish a general rule in spite of its historical particulars?

Although the complementarian view is alive and well both in North America and in Germany, it is not uncontested. Due in part to this controversy, there has been an increasing stream of evangelical academic publications dealing with relevant biblical interpretation and historical background studies (Mickelsen, 1986; Piper \& Gru-

2 As may be quickly surmised from the CBE website, www.cbeinternational.org. See also the foundational collection of essays in Mickelsen (1986). 
dem, 1991; Clark Kroeger \& Clark Kroeger, 1998; Smith, 2000;3 Winter, 2001; 2003), as well as with women in church history (Tucker \& Liefeld, 1987; Tucker, 1988; Conrad, 1998; Eulenhoefer-Mann, 2003). In the German context, one work that deserves special mention, because of its comprehensive and balanced treatment of the relevant issues, is Schmalenbach (2007). However, there are surprisingly few studies of an empirical nature, looking at how women actually fare in leadership (Brown Zikmund et al., 1998; Moreton \& Newsom, 2004a; 2004b). There are of course many denominations and organisations that continue to refuse women access to offices of leadership and teaching. ${ }^{4}$ But how do women fare in evangelical structures that endorse their involvement? What are factors that hinder their advancement?

\section{Evangelicals and the gospel of the kingdom}

Because of the importance of the Bible to evangelicals, one would expect biblical interpretation with a conservative bent to be a key factor hindering women from obtaining leadership positions, even in settings that are in principle egalitarian. Obviously, the Bible can be used to argue for a hierarchical or a complementarian view of women's roles in church, family, and society. However, this is not the only way the Bible can be read, even from an evangelical perspective, and a significant number of evangelicals read it differently. Before moving on to the empirical part of this article, it is important to make this point: although evangelical tradition and theology can indeed be drawn on to justify placing various restrictions on women, when read differently, they can also be seen to support an egalitarian view.

3 This volume, which supports female leadership, is particularly significant, since it was commissioned by the World Evangelical Fellowship and has also been translated into German (Smith \& Kern, 2000).

4 The ESV Study Bible, for instance, published in 2008, includes no women among the 95 contributors to its study notes and articles. In South Africa, one of the smaller reformed churches in South Africa (the "Gereformeerde" church; GKSA) continues to exclude women from the offices of elder and minister. In 2003, women were allowed to be deacons, but this decision was reversed in 2006 (Van Deventer, 2005:686). In 2009, this reversion was reversed (GKSA, 2009:680 ff.), so women can now be appointed deacons. In the other reformed churches (e.g. the Dutch Reformed Church;DRC), the Netherdutch Reformed "Hervormde" - Church of Africa; NRCA), and the Uniting Reformed Church of South Africa; URCSA), women can be deacons, elders and ministers. 
For this to happen, the exegesis of individual passages needs to be re-evaluated and the broader essence and implications of the gospel need to be recognised and applied. As a growing number of evangelicals realise, the gospel is not just about individual salvation; this is only one of its dimensions. It is after all the gospel of the kingdom (Matt. 4:23; 9:35; 24:14). This kingdom is not so much a realm as it is the reign of God. Its authoritative claim, coming from God as King and Christ as Lord, applies to individuals, but also to the communities in which they live - including their practices of leadership and their view and treatment of women. It has implications for their world, their social environment, and even for their natural environment (creation), since the scope of salvation and of God's reign is cosmic and universal, not limited to the heart and inner life of believers. One counterpart of this truth about God is that being a Christian brings with it social responsibility, something that has not always been recognised by western evangelicals because of their reaction to the social gospel in the late nineteenth century. The Lausanne Covenant, the foundational statement coming out of the first International Congress on World Evangelisation at Lausanne in 1974, includes an entire section on this responsibility (art. 5) with a clear commitment and an acknowledgement of the failure of the past. It is not a different social gospel at all, but something that is inherent and integrated in the gospel as Jesus preached it (cf. Isa. 61:1; Luk. 4:16-19; "good news to the poor").

This dynamic understanding of the kingdom leads to a third key term: transformation. The gospel of the kingdom is not or not just about right belief; it is not stagnant information. It is a story that is restorative and transformational in its thrust. This gospel is a dynamic force: the power of God (Rom. 1:16). Its aim is the transformation of individuals, of the broader reality, the context, in which these individuals live, and ultimately of all creation. Transformation has been a part of the evangelical vision from the beginning; the Puritans and Pietists looked forward to better conditions, "einen besseren Zustand" (Philipp Jakob Spener in Pia Desideria), ${ }^{5}$ in the church and to the latter-day glory promised by the Old Testament prophets. In the twentieth century, this vision remained rather vague and general, or it was largely limited to certain aspects of church life. The Lausanne Covenant indicates a turn toward a more specific, deliberate, and systematic approach to transformation - and with it,

5 This better future is the subject of chapter six (Spener, 1841:49-61); the phrase appears in the title (p. 49). 
a belief in social action against oppressive structures and practices as a paradigmatic concept inherent in the Christian gospel; this is exemplified by, for instance, Samuel and Sugden (1999, but based on 25 years of reflection on missionary work) in relation to mission among the poor and Sider (1978) in relation to economics and international justice.

One area where this transformational and anti-oppressive paradigm - and exclusion (of women from leadership) is a form of oppression (Kretzschmar, 1995:151 ff.) - still needs application is in relation to women and the continuing dominance of men in society, church, and culture, that is, patriarchy. Even though the western world has largely deserted patriarchy in its explicit formal and legal forms, this has not automatically led to improved conditions for women. Implicit or informal patriarchy, consisting of phenomena such as gender bias, stereotypes, and the domination of a male perspective, continues to be a formidable force even in the West. It prevents women from rising to higher leadership positions to such an extent that the term glass ceiling is frequently evoked as a metaphor for the invisible processes and structures that bring this about. Evangelicals have a responsibility to work to overcome such barriers, especially if they are involved in mission, a point argued more extensively in Kretzschmar (1995).

Evangelicals, then, are not conservative by necessity, or because their tradition requires it as a matter of principle. They will be conservative on some points, to maintain evangelical faith, but a truly evangelical understanding of the gospel, of the kingdom of God, and of the concomitant transformation simultaneously opens avenues for change. Not accepting the status quo, after all, is part of the warp and woof of evangelicalism. In other words, evangelicalism cannot be fully conservative if it wants to remain faithful to itself. There will always be those who find within the gospel and within the evangelical tradition the inspiration to launch a campaign for liberation and reform, whether they be Martin Luther King jr, William Wilberforce, William and Catherine Booth, or Frances Willard.

One such would-be evangelical agent for change and transformation, inspired by an emphasis on the kingdom-of-God paradigm, is YWAM.

\section{WWAM}

YWAM was founded by Loren Cunningham in 1960 as an international, interdenominational, and evangelical missionary organisa- 
tion with a focus on young adults. Under the motto, "To know God and to make Him known", YWAM operates in over 1000 locations in more than 170 countries with close to 18000 staff. Its activities, while widely diverse, are covered by three main categories: evangelism, training, and mercy ministry (or humanitarian aid; YWAM, s.a.a). ${ }^{6}$ Its training branch includes the University of the Nations (UofN), which issues non-accredited Bachelor's and Master's degrees in a number of disciplines. The formal stance of YWAM on women in leadership may be surmised from the following points.

\subsection{A platform for women}

From the beginning, Loren Cunningham and his wife Darlene have given women a platform to teach or lead - perhaps not surprising, considering that Loren Cunningham's mother began preaching regularly at the age of 17 and was an ordained Assemblies of God pastor (Cunningham \& Rogers, 1984:15, 21). The most influential female leader in YWAM is Darlene Cunningham herself, who has long been a popular speaker in YWAM schools and conferences. By regularly running a three month programme called Leadership Training School, she has impacted many of the organisation's leaders (YWAM, s.a.b). Her husband describes her as a co-founder and coleader, adding: "My wife ... is a leader, a leader of leaders, and a trainer of leaders. I don't know of a woman training more international missionaries than Darlene." (Cunningham 2000:236.) Other women who have been significant early teachers and leaders include Jean Darnall, Corrie ten Boom, Joy Dawson (all influential speakers), Landa Cope (International Dean of the College of Communications at the UofN), and Judy Smith, who together with her husband oversees the more than 30 Schools of Biblical Studies within the UofN network, in which many women lead and teach Bible survey and exegesis.

\subsection{Formal statements}

At an International Staff and Leadership Conference in Manila, Philippines, in August 1988, the Manila Covenant was presented by YWAM leadership as a foundational statement for the mission (YWAM, s.a.c). This Covenant was confirmed by 1500 YWAM staff participating in this conference. It lists twenty different allegiances; one of these is: "We affirm that God wants both young and old, male

6 The story of YWAM's beginnings is told in Cunningham and Rogers (1984). 
and female, in positions of leadership and responsibility in our mission." (YWAM, s.a.c.)

This formal position was solidified when YWAM's Foundational Values were officially accepted in 1992 (Green, 2004). Although this date is relatively late, most of these 21 values summarise what had been common practice from the beginning of the movement. They are frequently referred to and carry substantial weight in the organisation. Value number twelve specifically refers to the issue of women: "YWAM is called to value each individual. We believe all races, ages, cultures and individuals - male and female - have distinctive contributions and callings."7 In February 2004, a revised version of YWAM's Foundational Values was released (Green, 2004). In this revision the values were reformulated and the number was reduced to seventeen. The value concerning individuals, now number fourteen, was rephrased as:

YWAM is called to value each individual. We believe in equal opportunity and justice for all ... We are committed to honoring God-given leadership and ministry gifts in both men and women. (YWAM, s.a.d.)

None of the other values differentiate between male and female. All staff are to practice these values, even if some of them culturally and traditionally have often been associated with either women or men (eg. hospitality, leadership).

Also relevant is a collection of statements adopted as a result of a consultation on mercy ministries in 1998 which dealt with the question of how to best care for people. In relation to gender injustice it states:

We have been particularly challenged by gender injustice throughout the world and specifically as it exists within our mission. We recognize that the image of God is carried by both men and women: both are required at all levels of the mission in order that YWAM more completely reflect that image. (UofN, 2005b:343.)

7 The original version of YWAM's Foundational Values is included at the beginning of the University of the Nations School Leader's Reference Guide (UofN, 1995). 


\subsection{Instructions to University of the Nations course leaders}

The University of the Nations reference guide (UofN, 2005a) provides course leaders with an introduction to University of the Nations's regulations, standards, and principles. According to this guide, "at least some of the teachers should be international ... and [teachers] should include both men and women" (UofN, 2005a:92). It also includes an article on the abuse of authority. This article states: "When women are not given authority or are not recognized as equals to men through respect for their opinions, then authoritarianism is sure to follow." (McClung, 2005:160.) In order to facilitate this, the recommendation is made that "more men and women ... teach on women in ministry and women in leadership" (UofN, 2005b:343). A particular emphasis is put on men teaching on this issue by stating that there is a special need for men to speak on the topic of women in leadership and gender issues, "so that these are not just viewed as 'women's problems'" (UofN, 2005b:346).

\subsection{Why not women?}

In 2000, Loren Cunningham together with David Hamilton published the book, Why not women? A biblical study of women in missions, ministry, and leadership. The book rapidly became known in YWAM as Cunningham's book on women in leadership, and it is widely read in the organisation. It presents a clear egalitarian view. It should be pointed out how unusual it is for Cunningham or YWAM to take such a clear stance on a controversial issue. In order to keep YWAM interdenominational, he has often held back his opinion on theological issues for the sake of unity, giving him a reputation for reticence or even silence when it comes to controversial issues. Obviously, then, Cunningham considers the issue of women leading and teaching so crucial and foundational that no compromise can be made for the sake of unity.

\subsection{Recent initiatives}

In September 2002 YWAM organised the first international YWAM conference on global women's issues in Kuala Lumpur, Malaysia, called Connexity 2002 (Anon., 2002). More than 400 YWAM staff from 53 nations participated in the four days of the conference (Tanashya \& Buenting, 2002). The invitation to the conference said: "It is not an exclusive women's event but is for everyone who desires to see a greater release of women within YWAM and beyond." (Anon., 2002.) In 2006, Paul and Susi Childers, long-term YWAM staff, brought out a booklet titled, $A$ voice for the voiceless: 
30 days of prayer for the voiceless. In its foreword, Loren Cunningham calls gender injustice one of the greatest global challenges of the 21st century (Childers \& Childers, 2006). The aim of this prayer guide was "to issue a call to prayer and action" for women who experience injustice because of gender. The goal of Childers was to distribute 100000 of these prayer guides to raise awareness of gender injustice and to mobilise as many people as possible inside and outside of YWAM to pray for the gender issues described in the prayer guide, such as domestic violence, female genital mutilation, and honour killings.

Initiatives and publications like these leave the impression that YWAM has increasingly taken an active stance on behalf of women; more is involved than mere lip service. This makes YWAM a good place to study how women actually fare in terms of leadership roles in an evangelical organisation where female leadership is accepted in principle. For practical reasons, the scope of the research was limited to Germany, where both authors are involved in teaching and leadership. YWAM, Germany was founded at an early stage of the organisation's development (1972), and it has been a relatively large and influential part of the organisation, which also makes it an appropriate choice.

\section{Being a leader in WWAM Germany}

It quickly became clear that at least in YWAM Germany there remains a gap between theory and confession on the one hand and the reality of leadership on the other. There has never been a female national leader. In June 2007, when the following statistics were collected (Hornstra-Fuchs, 2009:42-51), each of the six existing training locations was being led by a leadership team, none of which had a woman as its main leader. Although approximately $60 \%$ of YWAM Germany's 206 staff were women, less than $30 \%$ of these leadership teams were female. The National Board of Directors consisted of six men and one woman. Why is this the case?

\subsection{Methodology}

Since the Bible is presumably the highest authority for evangelicals, considered binding in all matters of faith and practice, the initial hypothesis was that conservative and non-egalitarian interpretations of Scripture are at least one important reason for this underrepresentation of women in leadership positions. Because YWAM staff are drawn from a wide variety of church backgrounds, they may 
well continue to be influenced by more traditional theology and interpretation.

In order to test this hypothesis and to uncover other factors that contribute to the observed under-representation, a series of semistructured interviews consisting of mostly open questions was conducted in June and July of 2008. Seven interviewees were selected, all with at least ten years of involvement with the organisation and with substantial leadership experience. Three of the interviewees were female, four were male. Male interviewees were included because male leaders influence the accessibility of leadership positions to women; all four males selected have been involved in appointing new leaders. It was hoped that their inclusion would reveal aspects otherwise overlooked.

The interview questions fell into five larger thematic groups. One cluster of questions focused on the church background of the interviewees and its formal position and practice relating to women in leadership. A second cluster of questions dealt with both the awareness and the interpretation - whether complementarian or egalitarian - of the interviewees of relevant biblical passages. The interviewees were asked which passages they considered to be key passages and how they understood them. A third cluster asked questions about important role models and their gender. A fourth, extensive block of questions dealt with the process of selecting and becoming a leader. It examined issues like stereotypes, leadership image and values, the role that the gender of potential candidates play, and self-confidence. The aim of cluster three and four was to unearth which factors besides biblical interpretation play a role. A fifth cluster was connected with YWAM's Foundational Value 14 quoted above (section 4). It sought to establish how the interviewees assessed YWAM practice in this regard. For example, they were asked whether they thought that a problem existed, and if they answered yes, what the reasons might be and what course of action they would propose.

Each interview lasted between 80 and 110 minutes. Five interviews were taken in person and two by telephone. The interviews were recorded and transcribed in literary (non-phonetic) language. Each transcript was sent to the interviewee for correction and validation. In a qualitative content analysis the transcripts were analysed according to Mayring (2007:56-77). Each interview was summarised in the form of a table with three levels of abstraction. On the highest level of abstraction, categories (types of answers) and subcategories were determined inductively for each question. 


\subsection{A summary of the results obtained}

The interviewees originally came to YWAM from diverse church backgrounds, ranging from Lutheran to charismatic and from hierarchical (in two cases) to egalitarian (in one case; the others were somewhere in between). Five of them had experienced mixed leadership teams, although the main leader or pastor had always been male. In most cases, at least some restrictions had applied to women. It stood out that only two interviewees, both male, remembered hearing any formal teaching on the topic of women in leadership in their churches of origin, one from a hierarchical and the other from an egalitarian perspective. Today both are egalitarians.

When it came to the Bible, the three female interviewees did not seem to have much knowledge of the relevant passages and their interpretations nor did they express much awareness of the existence of a complementarian and an egalitarian position on the issue of female leadership. This is striking, because their ministry as leaders depends on one set of interpretations rather than another being true. They were more likely to answer with general considerations, like Jesus and Paul both including women and the observation that many women are gifted in leadership and teaching. In contrast, three of the four male interviewees appeared relatively well informed and could articulate a clear opinion. Two of them expressed an egalitarian position. The third took a fairly traditional point of view, the only interviewee to do so. In his view, women can be involved in leadership in the church as long as they are not the main leaders, since eldership is solely reserved for men. Although he did not refer to the concept of biblical manhood and womanhood, it may be assumed that he is sympathetic to the complementarian position.

In respect to role models, the female interviewees tended to have more women as role models, and the male interviewees more men. It seems likely that female role models have a different function for women than for men, and that their relative absence in YWAM, Germany impacts women and men differently. Women may look to female leaders to develop their own, personal concept of being a leader; therefore, when there are few female role models, they struggle to see themselves as (potential) leaders. Men may need female role models to come to accept female co-leaders or superiors. A lack of female role models may reinforce a subconscious image of the leader as male.

A significant section of the interviews explored the process of becoming a leader. When asked for criteria that a leader has to fulfil, 
the interviewees emphasised character and abilities, particularly people skills; gender and age were considered to be of little importance. Especially clear was the response to a series of statements:

- "Women do better under the leadership of a man than being the main leader." Six interviewees answered with no.

- "The final responsibility should be with a male leader." Six answered with no; for the one remaining interviewee this only applies to the office of elder, which he understands as the head leadership of a church or a Christian organisation.

- "A woman can be as good a leader as a man." All interviewees answered with yes.

- "Because of the way God made the woman she is happiest at home with her family." With some qualifications, all interviewees disagreed with the statement.

- "Women and men are equal in God's eyes." All seven interviewees agreed.

This lack of formal objections and hindrances implies substantial openness, at least in principle, to female leadership. At the same time, a certain amount of generalisation and stereotypes related to gender came to the fore. When asked whether women and men approached leadership the same way, four answered with yes, but all seven went on to list characteristics of how women lead and how men lead which were clearly different and matched common stereotypes: women supposedly were more caring, relational, emotional, and nurturing, whereas men were harder, more factual, and more formal. In other words, all interviewees actually believed women lead differently after all. Stereotypes like these may unwittingly play a significant role.

The male interviewees expressed greater self-confidence and appeared to have been more eager and ambitious; all four claimed to have had no or hardly any doubts about their leadership ability beforehand, whereas all female interviewees spoke of past or present doubts and fears. Interestingly, all male interviewees claimed their gender did not play a role in their becoming a leader, whereas for two female interviewees it did (the answer of the third was ambiguous). Paradoxically, then, maleness is not an issue in the appointing of leaders, but femaleness is. 
Although none of the questions asked for it directly, on occasion interviewees referred to the importance of family as a value. This was usually taken to imply that the mother stays at home with the children, at least while they are young, and may therefore not be available for leadership positions.

Perhaps the most important result from this cluster of questions is related to the procedure of selecting and appointing new leaders. One does not apply for a leadership position. Occasionally, someone is the carrier of a new vision, starts a new ministry, and therefore more or less automatically becomes the leader. More commonly, new leaders are chosen, asked, and appointed by the incumbent leadership. Since these are mostly male, especially in the National Board of Directors, women largely depend on male leaders for their promotion.

In answer to the question whether YWAM, Germany puts Foundational Value number 14 into practice, five interviewees answered with yes. When asked why there are far more men than women especially in higher leadership positions, most of the reasons given related to women (eg. lack of willingness or suitability). Fewer reasons related to male actions and attitudes as well as to the role of tradition in YWAM, in the church, and in the broader culture. Somewhat in contradiction to answers for the first question regarding Foundational Value 14, six interviewees did see a need for action; only one interviewee did not. When asked what needed to be done, a broad range of suggestions was proposed. In contrast to the previous question, these related more often to men than to women. Among them were: the men should take more responsibility at home and in the family, they should step back and make room for women, and they should deal with their reservations and stereotypes relating to women. Several proposals sought to remedy traditional role patterns and influence. Encouragement was recognised as an important need. It was also suggested that women in leadership should be made into an issue. The answers showed insight into the hidden factors that keep women from taking leadership positions; this is surprising, because these factors were hardly acknowledged in previous answers.

\subsection{Interpretation and discussion of these results}

The aim of the research project was to identify reasons for the under-representation of women in leadership positions within YWAM, Germany. Contrary to the original hypothesis, explicit interpretation of relevant Bible passages did not seem to play an 
important role, at least not in a direct way. Whether the interpretation of Scripture played an indirect role through influencing society and the church in the past could not be ascertained within the framework of this research, although it seems plausible. But if so, the direct influence would come from tradition and church background, not from Scripture.

The following arguments led to the rejection of the original hypothesis. Most of the leaders interviewed did not remember any deliberate biblical teaching on women in leadership in their churches of origin. The female interviewees were not very knowledgeable on the relevant Bible passages; they could at best list only a few and they could not explain the discussions about their interpretation. Their main argument to support their egalitarian practice - after all, all three are leaders - was a common-sense argument: since God had gifted them for leadership, it had to be right. Three of the four male interviewees knew the relevant biblical material quite well, but since two of them are egalitarians, their theology does not explain female under-representation. One male leader did express reservations regarding female leadership and professed a moderately complementarian understanding: women could lead, but they should not hold a main leadership position in a church or a Christian organisation. However, this leader also claimed to have been discreet about this conviction, so it seems likely that his views played a minor role in the appointment of leaders.

This result is surprising, because of the great importance and authoritative status habitually ascribed to the Bible by evangelicals. On this point at least, it turns out, it is not Scripture that determines faith and practice. The following factors did appear to play a role.

\subsubsection{Church background}

Although most of the churches of origin of those interviewed had not offered any formal teaching on women in leadership, they did have an established practice, which in most cases included certain restrictions for women. There was therefore indirect teaching by example, which proved to be quite effective: all churches managed to maintain their practice. Interestingly, the one male interviewee from a hierarchical church background who had later embraced an egalitarian view had done so by consciously and deliberately engaging the issue. In the absence of conscious reflection, it appears likely that the interviewees continued to be influenced by examples from their past. 


\subsubsection{Lack of female role models}

Not only had there been a lack of female role models in their churches of origin, but this continued to be the case after they had joined YWAM, due to the under-representation of women in higher leadership positions. The same under-representation exists in German society in general, which exacerbates this dynamic. In Germany, only about $10 \%$ of top positions in politics, research, and teaching are occupied by women. In 2007, only one woman served on the legal boards of the 30 largest German corporations. None of Germany's sixteen states is being governed by a female prime minister. Chancellor Angela Merkel is the first woman to hold this office and she has only done so since 2005 (Schneider, 2007:23 ff.). All of this makes it harder for women to begin to see themselves as leaders. It likewise makes it harder for men to recognise potential leaders in women and to consider them for leadership positions; it serves to confirm the stereotype that leadership is male.

\subsubsection{Lower self-confidence of women}

The female interviewees expressed considerably more doubt, fear, and lack of self-confidence and initiative than the males. This should not be taken to mean that lower self-confidence is an inherently female attribute; there are good social and other reasons why women would be less confident. At least in part, this factor derives its strength from the lack of female role models and the acceptance of masculine stereotypes (see point 6 below) of a leader. This may well leave many women feeling that they cannot live up to the ideal. There obviously is room here for leadership to make a difference by encouraging emerging female leaders.

\subsubsection{Family responsibilities}

Although the interview questions were not set up to cover this area, family responsibilities, that is, motherhood, did emerge as a factor limiting the involvement of married women in leadership. This may be another point where church background, missing role models, and a traditional understanding of womanhood play a role (the importance of family did not lead to the consideration that perhaps the father should stay at home). YWAM's Foundational Values do indeed address the importance of family. It is interesting to observe, however, that they do not require or expect women to stay at home with the children. Instead, Foundational Value number 15 states: "We encourage the development of strong and healthy family units, with each member sharing the call to missions and contributing their 
gifts in unique and complementary ways." This actually expects all members of the family to find their place in ministry in accordance with their gifting. As a non-profit volunteer organisation, the YWAM setting offers unique flexibility and opportunity for part-time involvement, flexible working hours, and job sharing. A number of families have made the most of these flexible work opportunities. However, if YWAM truly wants to practise its family value, more husbands may have to spend more time at home to enable the ministry of their wives.

\subsubsection{Stereotypes and leadership image}

Although the interviewees did not exhibit much awareness of it, there were indications that gender stereotypes and a masculine leadership image, elements of informal patriarchy, are a significant influence. This would make it more difficult for women than for men to aspire to be a leader or to be considered for a position. YWAM culture plays a role here as well, since it celebrates the kind of leader who is bold, strong, confident, active, visionary, pioneering, et cetera; women may find it inappropriate to adopt this style of leadership.

\subsubsection{Incumbent leadership}

In YWAM a new leader is usually selected and appointed by other leaders. There is no convention of applying for leadership positions. This is probably the most important reason for the under-representation of women in leadership positions. Since the incumbent leadership is mostly male, female leadership candidates depend on male leaders for their promotion. Not only are these leaders influenced by male stereotypes and leadership images, they are also more likely to prefer those candidates most like themselves, that is, other males (Rickens, 2008:125, drawing on work by Michael Hartmann). Incumbent leadership, then, holds the key to transformation.

\subsubsection{Comparisons}

These results show interesting parallels to research conducted by Schneider (2007) and Habermann-Horstmeier et al. (2007) on women in higher management positions in Germany as well as with a study by Moreton and Newsom (2004a; 2004b) of female chief academic officers in evangelical colleges and universities in North America. Schneider (2007) and Habermann-Horstmeier et al. (2007) do not discuss role models as such, but the lack of female networks is listed as a hindrance by female managers (Habermann-Horst- 
meier et al., 2007:30, 46). This at least shows the importance of knowing people of one's own gender in similar positions. Moreton and Newsom (2004b:325) do cite role models as an important factor.

As for self-confidence, Schneider (2007:107) states: "Many studies attest that women in leadership positions have comparatively low skills in self-promotion."8 Her findings confirm this generalisation. Women tend to give themselves low grades for self-marketing (Schneider, 2007:110). According to Habermann-Horstmeier et al. (2007:29f, 45 ff., 134), lack of assertiveness, lack of self-confidence, and poor self-marketing were among the main hindrances women in leadership positions had experienced on the way.

It does not come as a surprise that family and parenthood can be a significant hindrance for women (and not, or much less, for men). The managers questioned by Schneider (2007:61, 93, $166 \mathrm{ff}$.) considered it the second most important reason for the under-representation of women in leadership positions; in HabermannHorstmeier et al. $(2007: 30,46,134)$ it emerged as the first most important reason. This factor is also mentioned by Moreton and Newsom (2004b:325): "Many Christian women spend a great portion of their adult lives raising children and are unable to maneuver the necessary academic ladder for a top-level academic position." They make the observation that the marriages of those women who do hold a chief academic office often are non-traditional, meaning that the husbands take "roles in order to support their wives and children" - thus putting into practice the values stated by YWAM.

That leadership stereotypes match male but not female stereotypes is a well-established and apparently global phenomenon: "Think manager - think male"; the characteristics required to be a good manager are more readily ascribed to men as a group than to women (Schein et al., 1996:33; Schneider, 2007:58-61). In Schneider $(2007: 93,166)$ and in Habermann-Horstmeier et al. (2007:46, 134), preferring male candidates for leadership positions by males is one of the three most important hindrances named by women aspiring to higher management positions: males are more readily seen as suitable candidates since they match the stereotypical image of a

8 "Viele Studien bescheinigen Frauen in Führungspositionen vergleichsweise niedrigere Selbstdarstellungsfähigkeiten." 
leader. Here, too, incumbent leadership, mostly male, is a factor of major importance (Schneider, 2007:59 ff., 67-70).

\section{Conclusion}

The "glass ceiling" is alive and well, and obviously also exists in YWAM. The reasons for the under-representation of women in leadership positions in YWAM are not that different from those in, for instance, the business world; apart from church background, each of the factors uncovered has clear parallels elsewhere. Where explicit patriarchy is rejected, informal patriarchy proves quite resilient and effective in obstructing transformation. It is ironic that evangelicals who claim to be different to the world turn out to be so similar to it.

YWAM Germany looks at each job opening individually, considering who might fit the position. However, the fact that women in Germany are under-represented in leadership teams - mostly for reasons they cannot change - is not taken into consideration. If YWAM means what it says in its statements, and if it and other egalitarian evangelicals want to do full justice to their tradition, more needs to be done, so that the gospel can be good news to women, too. As argued in section 3, transformation is inherent in the gospel, but it does not take place automatically or even by offering better interpretations of Scripture, although the latter is important. It requires deliberate action, for which incumbent leadership holds the key (5.3.6). It is a leadership task to envision a different future (with women leading) and then to take initiative to influence the group they lead to get them there. At this point, may we remind YWAM and this includes us, the authors - of its Foundational Value number 12: "YWAM is committed to doing first, then teaching". Change requires more than statements or teaching, it requires doing - such as male leaders who actively encourage and promote women with leadership potential.

However, as long as there is little or no awareness of an issue and its causes, such action remains unlikely. YWAM's confession of equal opportunity for women by itself cannot overcome the hidden barriers that exist as long as they remain hidden. In the tradition of William Wilberforce, therefore, change must begin with drawing attention to this ethical problem and its roots - as attempted in this article. 


\section{List of references}

ANON. 2002. Youth With A Mission is planning Connexity 2002, the first international YWAM gathering on global women's issues. God's Word to women newsletter, 3(1), Summer. http://godswordtowomen.org/ newsletter/newsletters/summer2002.htm Date of access: 12 Aug. 2009.

BROWN ZIKMUND, B., LUMMIS, A.T. \& CHANG, P.M.Y. 1998. Clergy women: an uphill calling. Westminster: John Knox.

CHEMERS, M.M. 1997. An integrative theory of leadership. Mahwah: Erlbaum.

CHILDERS, P. \& CHILDERS, S. 2006. A voice for the voiceless: 30 days of prayer for the voiceless. Hawaii: YWAM.

CLARK KROEGER, R. \& CLARK KROEGER, C. 1998. I suffer not a woman: rethinking 1 Timothy 2:11-15 in light of ancient evidence. Grand Rapids: Baker Book House.

CONRAD, C. 1998. Der Dienst der ledigen Frau in deutschen Glaubensmissionen: Geschichte und Beurteilung. Bonn: Verlag für Kultur \& Wissenschaft.

CUNNINGHAM, L. 2000. A final word. (In Cunningham, L. \& Hamilton, D.J., ed. Why not women? A biblical study of women in missions, ministry, and leadership. Seattle: YWAM. p. 235-239.)

CUNNINGHAM, L. \& ROGERS, J. 1984. Is that really you, God? Hearing the voice of God. Seattle: YWAM.

EULENHOEFER-MANN, B. 2003. Missionary work of single German women in China from 1886-1914: a comparison between missiological theory and praxis on the mission field. Pasadena: Fuller Theological Seminary. (Ph.D. thesis.)

GALLAGHER, S.K. 2004. The marginalization of evangelical feminism. Sociology of religion, 65(3):215-237.

GEREFORMEERDE KERKE IN SUID-AFRIKA. 2009. Handelinge van die 50e nasionale sinode van die Gereformeerde Kerke in Suid-Afrika. Potchefstroom: GKSA.

GKSA

see GEREFORMEERDE KERKE IN SUID-AFRIKA

GREEN, L. 2004. Perspective: the quest at the heart of YWAM. http://www. ywam.org/articles/article.asp?AID=215 Date of access: 12 Aug. 2009.

GUSHEE, D.P. 2008. The future of faith in American politics: the public witness of the evangelical center. Waco: Baylor University Press.

HABERMANN-HORSTMEIER, L., ALBRECHT, K., BRAUN, B., GANTER, E. \& THIERER, M. 2007. Karrierehindernisse für Frauen in Führungspositionen - Ergebnisse einer empirischen Studie an 300 Frauen aus dem deutschen Mittel- und Topmanagement. Villingen-Schwenningen: STZ Unternehmen \& Führungskräfte.

HORNSTRA-FUCHS, F.A.S. 2009. Women in Christian leadership: an empirical study of "Youth With A Mission", Germany. Pretoria: University of South Africa. (M.Th. dissertation.)

INTERNATIONAL CONGRESS OF WORLD EVANGELIZATION. 1974. The Lausanne Covenant. http://www.lausanne.org/covenant Date of access: 30 Mar. 2010.

KRETZSCHMAR, L. 1995. Gender and oppression: a South African feminist underview. Missionalia, 23(2):147-161. 
MAYRING, P. 2007. Qualitative Inhaltsanalyse: Grundlagen und Techniken. Weinheim: Beltz.

MCCLUNG, F. 2005. Authority: its use and abuse. (In University of the Nations. 2005 University of the Nations Reference Guide. Lausanne: University of the Nations. p. 159-166.)

MICKELSEN, A.M., ed. 1986. Women, authority and the Bible. Downers Grove: InterVarsity.

MORETON, A.L. \& NEWSOM, R.W. 2004a. Personal and academic backgrounds of female chief academic officers in evangelical Christian colleges and universities. Part 1. Christian higher education, 3(1):79-95.

MORETON, A.L. \& NEWSOM, R.W. 2004b. Female chief academic officers in evangelical Christian colleges and universities. Part 2: Reflections on careers, marriage, and faith. Christian higher education, 3(4):313-328.

NEUBERGER, O. 2002. Führen und führen lassen: Ansätze, Ergebnisse und Kritik der Führungsforschung. 6. Aufl. Stuttgart: Lucius \& Lucius.

PIPER, J. \& GRUDEM, W., eds. 1991. Recovering biblical manhood and womanhood: a response to evangelical feminism. Wheaton: Crossway Books.

RICKENS, C. 2008. Geschlossene Gesellschaft! Managermagazin, (2):123127.

SAMUEL, V.K. \& SUGDEN, C. 1999. Mission as transformation: a theology of the whole gospel. Oxford: Regnum Books.

SCHEIN, V.E., MUELLER, R., LITUCHY, T. \& LIU, J. 1996. Think manager think male: a global phenomenon? Journal of organizational behavior, 17:33-41.

SCHMALENBACH, H.-M. 2007. Frausein zur Ehre Gottes - im Kontext verschiedener Kulturen. Marburg: Francke.

SCHNEIDER, B. 2007. Weibliche Führungskräfte - die Ausnahme im Management: eine empirische Untersuchung zur Unterrepräsentanz von Frauen im Management in Großunternehmen in Deutschland. Frankfurt am Main: Peter Lang.

SIDER, R.J. 1978. Rich Christians in an age of hunger: a biblical study. London: Hodder \& Stoughton.

SMITH, M.B., ed. 2000. Gender or giftedness: a challenge to rethink the basis for leadership in the Christian community - a study of the role of women. Manila: World Evangelical Fellowship Commission on Women's Concerns.

SMITH, M.B. \& KERN, I., eds. 2000. Ohne Unterschied? Frauen und Männer im Dienst für Gott: Leitungsaufgaben in christlichen Gemeinden und Werken - eine Herausforderung, die Grundlagen neu zu überdenken. Giessen: Brunnen.

SPENER, P.J. 1841. Pia Desideria: oder herzliches Verlangen nach gottgefälliger Besserung der wahren evangelischen Kirche, nebst einigen dahin abzweckenden christlichen Vorschlägen. Leipzig: Köhler.

TANASYAH, Y. \& BUENTING, D. 2002. Connexity focuses on females. http://www.ywam.org/articles/article.asp?AID=137 Date of access: 12 Aug. 2009.

TUCKER, R.A. 1988. Guardians of the great commission: the story of women in modern missions. Grand Rapids: Zondervan.

TUCKER, R.A. \& LIEFELD, W.L. 1987. Daughters of the church: women and ministry from New Testament times to the present. Grand Rapids: Zondervan. 
UNIVERSITY OF THE NATIONS. 1995. University of the Nations school leader's reference guide. Lausanne: University of the Nations.

UNIVERSITY OF THE NATIONS. 2005a. 2005 University of the Nations reference guide. Lausanne: University of the Nations. (In University of the Nations: resource tools. Lausanne: University of the Nations. [CDROM].)

UNIVERSITY OF THE NATIONS. 2005b. YWAM Mercy Ministries International: justice, gender and life-span issues, and best practices in member care. Lausanne: University of the Nations. (In University of the Nations. 2005 University of the Nations reference guide. Lausanne: University of the Nations. p. 343-350.)

UofN

see UNIVERSITY OF THE NATIONS

VAN DEVENTER, H.J.M. 2005. Why minds are changed: an inquiry into the decisions by the Gereformeerde Kerke in Suid-Afrika (GKSA) on the role of women in the church. Koers, 70(4):685-704.

WINTER, B.W. 2001. After Paul left Corinth: the influence of secular ethics and social change. Grand Rapids: Eerdmans.

WINTER, B.W. 2003. Roman wives, Roman widows: the appearance of new women and the Pauline communities. Grand Rapids: Eerdmans.

YOUTH WITH A MISSION. s.a.a. About YWAM. http://www.ywam. org/contents/abo_introduction.htm Date of access: 12 Aug. 2009.

YOUTH WITH A MISSION. s.a.b. Founders - Loren and Darlene Cunningham. http://www.ywam. org/contents/abo_wha_founder.htm Date of access: 12 Aug. 2009.

YOUTH WITH A MISSION. s.a.c. Manila Covenant. http://www.ywam.org/ contents/abo_doc_manila.htm Date of access: 12 Aug. 2009.

YOUTH WITH A MISSION. s.a.d. The foundational values of Youth With A Mission. http://www.ywam.org/contents/abo_doc_values.htm Date of YWAM access: 12 Aug. 2009.

see YOUTH WITH A MISSION

\section{Key concepts:}

evangelicals

women, under-representation in leadership positions

Youth With A Mission, Germany

\section{Kernbegrippe:}

evangeliese Christene

vroue, onderverteenwoordiging in leiersposisies

Youth With A Mission, Duitsland 
